\title{
Creativity and Multiculturalism: Literature Review
}

\author{
Marina Porto-Ribeiro ${ }^{1, *}$
}

Orcid.org/0000-0002-8634-9240

Denise de Souza Fleith ${ }^{1}$

Orcid.org/0000-0001-7512-8023

${ }^{1}$ Universidade de Brasília, Brasília, DF, Brasil

\begin{abstract}
This study examined journals articles, published from 2010 to 2015, about the relationship between multiculturalism and creativity. A literature search was conducted in the databases Capes, PsycNET and SciELO. Thirty articles that fit within pre-established inclusion criteria were selected. The articles were analyzed according to the categories: journal, country of production, target, sample, and instruments. There was an increase in the number of publications concerning this theme in the last years. Researchers from regions with high migratory flow, such as United States, Europe and Asia, seemed more interested in the matter. There was no publication neither from Brazil nor Latin America. The majority of the studies selected were empirical, quantitative, and used adult samples. The reviewed studies indicated a relationship between creativity and multiculturalism, mediated by psychological mechanisms and environmental conditions.
\end{abstract}

Keywords: Creativity, multiculturalism, biculturalism.

\section{Criatividade e Multiculturalismo: Revisão de Literatura}

\section{Resumo}

Este estudo examinou publicações em periódicos, no período de 2010 a 2015, sobre a relação entre multiculturalismo e criatividade. O levantamento foi realizado nas bases de dados Capes, PsycNET e SciELO. Foram selecionados 30 artigos que atenderam aos critérios de busca pré-estabelecidos. Os artigos foram analisados quanto às categorias: periódico, países de produção, objetivo de pesquisa, tipo de autoria, ano de publicação, tipo de estudo, abordagem do estudo, população pesquisada e instrumentos utilizados. Observou-se aumento das publicações sobre a temática nos últimos anos. Pesquisadores de regiões de alto fluxo migratório, como Estados Unidos, Europa e Ásia, demonstraram maior interesse pela área. Não houve publicação brasileira, tampouco latina. A maioria dos estudos encontrados era empírico, de abordagem quantitativa e investigou participantes adultos. Os estudos revisados indicaram, de forma geral, haver relação entre criatividade e multiculturalismo, mediada por mecanismos psicológicos e condições do ambiente.

Palavras-chave: Criatividade, multiculturalismo, biculturalismo.

* Mailing address: Universidade de Brasília, Instituto de Psicologia, Departamento de Psicologia Escolar e do Desenvolvimento, Campus Universitário, Asa Norte, Brasília, DF, Brazil 70910-900. Phone: (61) 3107-6830. Fax: (61) 3273-6378. E-mail: marinaportopsi@gmail.com 


\section{Creatividad y Multiculturalismo: Revisión de la Literatura}

\section{Resumen}

Este estudio examinó publicaciones científicas en revistas en el periodo de 2010 a 2015, sobre la relación entre multiculturalismo y creatividad. La búsqueda fue realizada en las bases de datos Capes, PsycNET y SciELO. Fueron seleccionados 30 artículos que cumplieron con los criterios de búsqueda preestablecidos. Los artículos fueron analizados de acuerdo con las categorías: revista, países de producción, objetivo de la investigación, tipo de autoría, año de publicación, tipo de estudio, enfoque de estudio, población investigada e instrumentos utilizados. Se observó un aumento de las publicaciones sobre el tema en los últimos años. Los investigadores de las regiones de alta migración, como Estados Unidos, Europa y Asia han demostrado mayor interés en el tema. No se encontraron publicaciones brasileñas o latinas. La mayoría de los estudios fueron empíricos, cuantitativos y con participantes adultos. Los estudios revisados indican, en general, que existe una relación entre creatividad y multiculturalismo, mediada por los mecanismos psicológicos y las condiciones ambientales.

Palabras clave: Creatividad, multiculturalismo, biculturalismo.

Multiculturalism is a growing and multifaceted phenomenon. Inglis (1996) highlights the popularization of the term multiculturalism and appoints three distinct but interrelated references for its use: demographic-descriptive, programmatic-political, and ideological-normative. The use of the term multiculturalism from the demographic-descriptive perspective reflects the existence of different races or ethnic origins in a society, a cultural mix that produces social meanings. That will be the focus of this study. The programmatic-political application of the concept, then, remits to programs and policies that were established to cope with the ethnic or racial diversity. The ideological-normative use corresponds to a model based on the sociological theory and on the ethical-philosophical consideration that emphasizes the existence of ethnic diversity and the need to guarantee that individuals from non-dominant cultures have equitable access to the constitutional principles and the shared values in society.

As they engage in the new culture, the individuals who go through multicultural demographic experiences, working, studying or living together in various environments, start to assess and question their own beliefs, customs and traditions (Tadmor, Hong, Chao, Wiruchnipawan, $\&$ Wang, 2012). An increasing number of people identify with cultures different from their own (Mok \& Morris, 2012). Sam and Berry (2010) highlights that refugees, people claiming asylum, immigrants, expatriates, indigenous people, and ethnic minorities are the most studied samples in research on multicultural identities. Since the 1950's, Malzberg and Lee (1956) have investigated social and psychological adversities deriving from the multicultural identification processes.

More recent studies have revealed very positive implications of this type of experience. Different benefits have been related to multiculturalism, including: adaptability, leadership, and problem-solving ability (Friedman \& Liu, 2009); professional success (Tadmor, Galinsky, \& Maddux, 2012); expansion of social networks (Mok, Morris, Benet-Martínez, \& Karakitapoglu-Aygun, 2007); and creativity (Crisp \& Turner, 2011; Leung \& Chiu, 2010; Saad, Damian, Benet-Martínez, Moons, \& Robins, 2012). Creativity, considered as a process through which something useful and original is created (Amabile, 1996), has been largely investigated in this relation. In a theoretical article, Goclowska and Crisp (2014) listed more than 10 studies, published between 2008 and 2012, about creativity and multiculturalism.

In view of the multicultural contrast, what would make an individual develop creativityrelated characteristics and competences or not? The psychological adaptation of migrants is a frequently explored phenomenon, especially 
in the international scientific community (Kuo, 2014, Sam \& Berry, 2010; Yoon et al., 2012). Researchers have studied different aspects, ranging from individuals and ethnic groups' characteristics to natives' attributes and attitudes in the host country (Aronowitz, 1984; Berry \& Sam, 1997).

Berry (1990), Berry, Kim and Boski (1987), Berry, Kim, Minde and Mok (1987), Berry and Sam (1997) investigated multicultural adaptation based on the behaviors and attitudes individuals adopt towards their native and new cultures. According to these authors, people can identify themselves with both, none or only one of the cultures, through a process that has been called acculturation. Four strategies have been appointed: assimilation, separation, marginalization, and integration.

Tadmor, Galinsky et al. (2012) verified that college students who adopted integration as an acculturation strategy scored higher on creativity measures when compared to individuals who adopted separation or assimilation as an acculturation strategy. Thus, the multicultural identification model based on the acculturation strategies would explain how multiculturalism relates with creativity.

Benet-Martínez, Leu, Lee and Morris (2002), however, appoint gaps in the conception of bicultural identity. According to the authors, the theory of acculturation strategies ignores how people deal with the two cultures in the integration strategy and the paradoxical perception of belonging to two cultures and, at the same time, to none (Benet-Martínez \& Haritatos, 2005). In response to criticism, Benet-Martínez et al. (2002) outlined a new theoretical construct to investigate individual differences in the ways bicultural identities are organized, thus focusing on the integrative acculturation strategy only.

Bicultural Identity Integration (BII) was proposed to measure to what extents bicultural individuals perceive their identities as compatible and integrated or opposed and hard to integrate (Benet-Martínez et al., 2002). The BII is high when the two cultural identities are perceived as interconnected, coherent or integrated; and low when they are perceived as opposed, separated or disintegrated (Benet-Martínez \& Haritatos, 2005). In line with what happened in the research on the acculturation strategies, creativity has also been related with the multicultural identification process described in the BII model. Bicultural individuals with high BII tend to be more creative than those with low BII (Cheng, Sanchez-Burks, \& Lee, 2008; Saad et al., 2012).

Besides these two possible explanations on the relation between multiculturalism and creativity, based on the individual's identification with the cultures, other theories have been proposed. Goclowska and Crisp (2014) summarized research in this area and proposed a theoretical model to explain the creative gain of people who identify with two cultural groups (bicultural). The authors described three essential components of cultural identification: (a) depth, which implies a degree of cultural engagement, learning, and processing of information on the new role played in the guest culture; (b) dual engagement, which involves the development of skills to see the world through different social identities, benefitting flexible and creative thinking; and (c) cultural distance, representing the dimension in which the predominant values, customs, and characteristics in both groups diverge, and consequently demand individuals to elaborate complex integrative solutions. The actual belonging to two culturally distant groups, experienced in depth, requires that individuals develop innovative ways of thinking and acting, encouraging their creative potential (Goclowska \& Crisp, 2014).

In addition, hypotheses have been raised that the emotional condition, whether positive or negative (Cheng, Leung, \& Wu, 2011), and the climate for inclusion $(\mathrm{Li}, \mathrm{Lin}, \mathrm{Tien}, \&$ Chen, 2015) moderate the relation between creativity and multiculturalism. To date, no consensus has been identified in the literature as to how multiculturalism can permit the development of creativity, but clear efforts have been made to investigate this relationship.

Based on these arguments, it is relevant to assess what has been explored and discovered thus far, aiming to understand the advances re- 
search has made in this field and to identify future research needs. According to Witter (1999), the analysis of scientific productions contributes to enhance the available knowledge, signaling what researchers have been most interested in, theoretical and methodological trends, the most studied samples, and other aspects.

In Brazil, little research has been done on the relation between creativity and multiculturalism. Many Brazilian studies on creativity exist, including literature reviews (Nakano, 2005; Nakano \& Wechsler, 2007; Wechsler \& Nakano, 2003; Zanella \& Titon, 2005), but the association of this construct with multiculturalism is still incipient. Some studies relate creativity with bilingualism (Mendonça \& Fleith, 2005; Zimmer $\&$ Alves, 2014). Although language proficiency can be associated with experience in different cultures, it can also exist without individuals' experience of multiculturalism.

The study's social relevance also derives from the greater incidence of different forms of multiculturalism in the contemporary world. With respect to the international migration flow, for example, the number of migrants around the world has increased by more than $41 \%$ in the past 15 years (United Nations, 2015). Beyond the migrants, their relatives should be taken into account, who can experience multiculturalism at home, even without ever living in another country. In a study on that variable by Chang, Hsu, Shih and Chen (2014), creativity was investigated in adolescent children of individuals from different nationalities. The authors found higher creativity rates in multicultural young people when compared to monocultural youth.

Considering that much has been discovered about multiculturalism and creativity and that opportunities for cultural exchanges have grown, a literature search is needed to present the state of the art on this problem, with a view to exposing gaps, suggesting future research, and founding public policy strategies. The objective in this study was to map articles published in journals between 2010 and 2015, aiming to investigate the relation between multiculturalism and creativity.

\section{Method}

To search the literature, three electronic databases were consulted, being one international and two Brazilian: the international database was PsycNET by the American Psychological Association, while the Brazilian databases were the Scientific Electronic Library Online (SciELO) and the Coordination for the Improvement of Higher Education Personnel (CAPES).

For the search, the following pairs of keywords were used: criatividade and multiculturalismo and criatividade and biculturalismo in Portuguese, and creativity and multiculturalism and creativity and biculturalism in English. Two selection criteria were set: type of study, centering the search on scientific articles published in journals only, and publication date, delimiting the period between 2010 and 2015 .

The survey was undertaken in October and November 2015, locating 126 publications that contained the investigated keywords, being 38 $(30 \%)$ in PsycNET, 85 (68\%) in CAPES and three $(2 \%)$ in SciELO. In a first check, the criteria publication type and year were applied, eliminating 14 productions $(11 \%)$ that did not fit into the categories of articles published in journals and five (4\%) that were published before 2010 . Fifteen $(12 \%)$ other articles were excluded because they were repeated in the different databases.

Hence, the abstracts of 92 scientific productions $(73 \%$ of the total) were analyzed to verify whether their content was compatible with the review objective. Most articles were found in the CAPES database $(n=69), 14$ others in PsycNET and nine were available in both databases. None of the articles came from SciELO.

\section{Procedures}

Based on the reading of the abstracts, we aimed to verify whether the 92 articles identified explored the two central constructs in this study, multiculturalism and creativity, in their objectives. Most of them investigated only one of the constructs. Although the remainder mentioned the terms multiculturalism and creativity, 
their research objectives were focused on other themes. Sixty-two articles were excluded (49\% of the total).

The remaining 30 articles ( $24 \%$ of the total) were fully read. The data from this reading were catalogued in a worksheet with the following analysis categories: journal, countries, type of authorship, year of publication, objectives, study design, methodological approach, research population, instruments used. To analyze the journals, the number of articles published per journal was verified. We also surveyed the journals' knowledge areas by reading the descriptions available on their websites and the languages the texts were published in.

To analyze the countries where the articles were produced, we observed the countries where the universities the authors were affiliated with were located, generally described in the notes to the article. To give an example, in the article by the authors Susannah B. F. Paletz, from the University of Maryland, Ella Miron-Spektor, from the Israel Institute of Technology, and Chun-Chi Lin from the National Taiwan University, the countries United States (USA), Israel and Taiwan were registered. For articles in which more than one author or more than one university were located in the same country, the country was counted only once, as the objective was to quantify the number of publications per year.

To assess the type of authorship, it was verified whether an individual or multiple authors wrote the articles. The publication year was catalogued according to the publication date of the journal.

To analyze the study design, we analyzed whether the articles were characterized as an empirical study, literature review, theoretical article, methodological article or case study. The criteria described in the Manual of the American Psychological Association (American Psychological Association, 2010) were used for this assessment. According to that manual, empirical studies are research reports with original data and generally contain an introduction, method, results and discussion. Literature reviews are critical assessments of previously published material whose characteristics are close to those of theoretical articles, the latter proposing new theories or analyzing existing ones, highlighting the advances; the structure of both is similar, without the common parts of empirical studies. In methodological articles, new methodological approaches are presented. Case studies involve investigations of individual, group, community or organizational scenarios.

When applicable, in the empirical articles and case studies, the approach and sample were also analyzed. The analysis of the approach considered the categories quantitative study, qualitative study or both. Fleith and Costa (2005) highlighted that this distinction is not simple. Therefore, in this study, we chose to adopt the criteria based on Breakwell (1995). The author described qualitative study as an analysis that describes and details the nature of processes, while quantitative study is the analysis that measures the frequency and magnitude of the processes. While the first is more related to meanings and definitions, the second is related to counts and measures.

The age range of the research population was assessed and classified in the categories: child, adolescent, adult student or adult professional. Participants up to 12 incomplete years of age were considered children and those between 12 and 18 years of age as adolescents, as defined in the Child and Adolescent Statute (Estatuto da Criança e do Adolescente, 1990). Participants over 18 years of age, undergraduate or MBA students and other professionals were classified as adults. In view of the distance between the students and the professionals' mean age, the adults were also classified in terms of occupation.

The creativity and multiculturalism measures used were only analyzed in empirical articles. In this analysis, the usage frequency and authors of the measures were catalogued. In some articles, more than one procedure was used to measure creativity or multiculturalism.

\section{Results}

To analyze the results, descriptive statistics were used, aiming to map the publication data, authorship, objectives and methods. The 
Table 1

Publications on Creativity and Multiculturalism between 2010 and 2015

\begin{tabular}{|c|c|c|}
\hline Publication & Study design & Countries \\
\hline Betz (2014) & Case study & Australia \\
\hline Chang et al. (2014) & Empirical & Taiwan \\
\hline Chang, Su, \& Chen (2015) & Empirical & Taiwan \\
\hline Chao, Kung, \& Yao (2015) & Literature review & Canada and China \\
\hline Cheng \& Leung (2012) & Empirical & Singapore \\
\hline Cheng et al. (2011) & Empirical & Singapore and Taiwan \\
\hline Cho \& Morris (2015) & Empirical & United States \\
\hline Chua, Morris, \& Mor (2012) & Empirical & United States \\
\hline Crisp \& Turner (2011) & Theoretical & England \\
\hline Crotty \& Brett (2012) & Empirical & United States and United Arab Emirates \\
\hline Fee \& Gray (2012) & Empirical & Australia \\
\hline Goclowska \& Crisp (2014) & Theoretical & The Netherlands and England \\
\hline Kharkhurin (2010) & Empirical & United Arab Emirates \\
\hline Klimczuk (2014) & Theoretical & Poland \\
\hline Krug (2013) & Case study & New Zealand \\
\hline Lee \& Kim (2011) & Empirical & United States \\
\hline Leung \& Chiu (2010) & Empirical & Singapore \\
\hline Leung \& Wang (2015) & Theoretical & China \\
\hline Li et al. (2015) & Empirical & China and Taiwan \\
\hline Maddux, Adam, \& Galinsky (2010) & Empirical & United States and France \\
\hline Moro (2014) & Empirical & France \\
\hline Nouri et al. (2013) & Empirical & Israel and Singapore \\
\hline Paletz, Miron-Spektor, \& Lin (2014) & Theoretical & United States, Israel and Taiwan \\
\hline Saad et al. (2012) & Empirical & United States and Spain \\
\hline Stahl, Makela, Zander, \& Maznevski (2010) & Literature review & Austria, France, Finland, Sweden and Switzerlan \\
\hline Storme et al. (2015) & Empirical & China and France \\
\hline Tadmor, Galinsky et al. (2012) & Empirical & United States and Israel \\
\hline Tadmor, Satterstrom, Jang, \& Polzer (2012) & Empirical & United States and Israel \\
\hline Viki \& Williams (2014) & Empirical & England \\
\hline Zhan, Bendapudi, \& Hong (2015) & Empirical & China and Singapore \\
\hline
\end{tabular}

30 studies of which we analyzed the full text are displayed in Table 1, including information about the study design and country.

A prevalence of articles with multiple authors $(n=25)$ over individual authors $(n=5)$ was observed. The number of publications per year has increased. Despite the lack of a linear growth in the number of articles, this theme has been more investigated in the past three years. Seven publications per year were located in 2014 and 2015 , more than at the start of the research period. In 2010, four publications were found, and 
three in 2011. Between 2012 and 2013, significant variation occurred, with seven publications in the first year but only two in the second.

A preponderance of empirical studies was observed ( $n=21$ articles). Five studies were theoretical articles; two were literature reviews and two case studies. None of the publications were characterized as a methodological study.

The nationality of the articles differed a lot. Universities from 18 different countries participated in the production of the articles on creativity and multiculturalism. The United States was the country with the largest number of productions $(n=10)$. The representativeness of the Asian continent in this analysis is strong, as 21 publications were produced in the region, being five from China, five from Singapore, five from Taiwan, four from Israel and two from the United Arab Emirates. Fourteen articles had European authors and three came from Oceania. No authors from the South American continent were identified, nor publications in Portuguese. Almost all articles were written in English $(n=29)$ and only one in Italian, published in the journal Interazioni.

The 30 articles analyzed were published in 21 journals. Most journals, from different knowledge areas, published only one article. Publications were identified in journals that selfdescribed as arts, human science, social science, philosophy, management, literature and psychology journals. Only four journals from the larger area psychology published more than one article, being: Journal of Organizational Behavior $(n=4)$, Journal of Cross-Cultural Psychology $(n=4)$, The Journal of Creative Behavior $(n=3)$ e Social Psychological and Personality Science $(n=2)$.

Creativity and multiculturalism are complex constructs, which can be investigated in different manners. In the articles in this review, creativity was investigated from the individual $(n=21)$, collective $(n=7)$ and both perspectives $(n=2)$. The multiculturalism construct was investigated from the individual perspective $(n=17)$; collective, considering teams, groups and families $(n=8)$; and from the environmental perspec- tive $(n=5)$, considering the multicultural society, context or community.

To get to know the studies better, the research objectives were analyzed. We grouped the studies with similar foci into categories. The identified propositions were organized in six groups: (a) explain the relation between multiculturalism and creativity through psychological mechanisms; (b) debate on or prove the existence of the relation or correlation between multiculturalism and psychological variables, including creativity; (c) analyze environmental conditions that favor creativity; (d) discuss the relation between bilingualism and creativity; (e) assess the impact of the type and structure of the creative task in multicultural contexts; (f) others.

In half of the publications analyzed $(n=15)$, the authors discussed mechanisms underlying the relation between multiculturalism and creativity. The identity or cultural identification $(n=5)$, cultural metacognition $(n=2)$, perceived cultural distance $(n=2)$, learning about the new culture $(n=2)$, emotional condition $(n=1)$, perceived conflict or threat in multicultural environments $(n=1)$, cognitive adaptation process $(n=1)$ and ability to navigate in different mindsets $(n=1)$ were studied as means or strategies to develop the creative potential in view of the multicultural experience.

A broader investigation was undertaken in six articles, in which we aimed to assess positive and negative effects of multiculturalism in psychological and behavioral variables, including creativity $(n=2)$ and to empirically evidence the relation between multiculturalism and individual or collective creativity $(n=4)$. In three publications, the researchers analyzed the conditioning elements of multiculturalism to promote creativity. The climate for inclusion $(n=1)$ and the public and institutional conditions in an industry $(n=1)$ were studied as mediators of experience in multiple cultures. In addition, the creativity of multicultural individuals was compared in two different sociocultural contexts $(n=1)$.

In two articles, the relation between bilingualism resulting from multicultural experience and creativity was investigated. The authors of 
two other articles discussed the importance of the specificity and structure of the creative task for the performance of multicultural teams or people. Three articles had different objectives. In one study, the difference in ethnic and cultural diversity was assessed in relation to innovation. In another, creativity was analyzed in a literary production by an author with multicultural experience. One article addressed the negative perspective of the relation between multiculturalism and creativity, discussing the potential of the negative social process to create intercultural obstacles and, consequently, suppress the creativity of teams with members from different cultures.

Concerning the method, two types of approaches were assessed, together with the sample in 21 empirical articles and two case studies. The analysis of the approach revealed that 19 productions were characterized as quantitative studies, two were qualitative studies (both case studies) and one adopted a mixed quantitative and qualitative approach. What the sample is concerned, it could be observed that most articles investigated adults. Eleven articles involved adult college students and four adult professionals. Only three studies investigated children and two adolescents. In three publications with empirical and case study designs, the participants' profile was not identified or documentary analysis was undertaken to develop the research.

In the analysis of the instruments, only the empirical articles with a quantitative approach $(n=19)$ were considered. Of this total, in $89 \%$, an instrument was used to measure the creativity; in $79 \%(n=15)$, at least one previously validated instrument was applied and, in $37 \%(n=7)$, an original questionnaire or task was used (elaborated by the author of the study) to measure the creativity. In $10 \%(n=2)$ of the studies, only one instrument was used to measure the construct, while all others employed more than one quantitative procedure to analyze the creativity.

The most frequent creativity tests in the publications were those elaborated by Guilford and Torrance. The Alternative Uses Test (Guilford, 1950, 1959, 1967) was used in five studies. Torrance's Test of Creative Thinking (Torrance,
1998), the short version for adults (Goff \& Torrance, 2002) or the version adapted for Chinese individuals, was used in five studies.

On the other hand, the multiculturalism construct was measured by means of psychometric instruments in less than half of the quantitative empirical articles. In the other publications, the authors departed from the information that multiculturalism existed, for example, in participants who had lived in different countries, which was considered sufficient to characterize them as multicultural without the use of other methods. Only $47 \%(n=9)$ of the empirical articles analyzed aimed to measure this construct. Two instruments were used in more than one publication, the Multicultural Experience Survey $(n=3$; Leung \& Chiu, 2010) and the Bicultural Identity Scale ( $n=2$; Benet-Martínez \& Haritatos, 2005). Instruments were identified to measure the intensity of exposure to multiple cultures, the subjects' identification with the maternal and host cultures, the knowledge on the new culture, the type of acculturation, cultural metacognition, and the distance between the cultures.

\section{Discussion}

One of the objectives in this review was to get to know and analyze how the relation between creativity and multiculturalism has been studied. The analysis of the articles suggests that, in general, the variables are interconnected. Two relevant aspects observed in research in this field stand out: the mechanisms underlying creative development in view of multiculturalism and the conditions that favor the relation between the constructs. In addition, two topics were identified that can indicate trends for future research: creativity measures and the definition of multiculturalism.

It could be observed that cultural identification through the adoption of acculturation measures (assimilation, separation, marginalization or integration) and biculturalism can be an essential process for a multicultural person to develop creativity. In addition, the perceived distance between cultures experienced, the learning about the new culture, the cultural metacogni- 
tion and fluency in another language have also demonstrated a mediating effect on the creative performance of multicultural subjects.

The conditions of the context in which multiculturalism takes place can influence the creative processes. People with a double cultural filiation answered the creativity tests differently depending on the culture they were living in (Kharkhurin, 2010). In work teams, it was observed that the climate for inclusion is fundamental to permit information sharing and, consequently, favor creativity (Li et al., 2015).

The importance of choosing the type and structure of creative tasks used in the studies and in the daily reality of institutions with multicultural individuals is enhanced. Storme et al. (2015) verified that results found when using a specific creativity task cannot be generalized to all types of creativity. In other words, assessing verbal creativity in a brainstorming task (divergent exploratory thinking) is not enough to conclude on a multicultural individual's general creativity. In addition, Nouri et al. (2013) found that culturally diverse teams benefit from specific instructions when they perform an executive task (convergent) and from general instructions when they perform a creative task.

Hence, the creative results of multicultural individuals or teams can vary according to the type and structure of the task performed. The analysis of the empirical articles in this review revealed that the majority used more than one type of creativity measure. That seems to be a need and a trend in research on the relation between creativity and cultural effects.

Great variation was identified in the concepts that defined the problems in each study, especially concerning the understanding of multiculturalism. Some authors described this variable as multiple cultures within the same country. For other researchers, multiculturalism happens when different cultures from two or more nations interact. In young people, multiculturalism was described in children who are born and grow up in other countries than their parents. Other authors studied the phenomenon based on two inconsistent social identities, such as a businesswoman or secular Buddhist.
In addition, different dimensions of the concept have been investigated. Multiculturalism was explored as an environment, individual or groups, experience and product. In some publications, no definition of multiculturalism was identified. In addition, the term multiculturalism is used in a broad sense. Rudmin (2009), for example, highlights that, between 1918 and 2003, more than 100 different cultural identity taxonomies were proposed, including multiculturalism. To analyze the transformations deriving from the multicultural experience of individuals or groups, Sam and Berry (2010) suggest that the term acculturation is more appropriate than multiculturalism, assimilation, globalization and biculturalism. It is important for future studies to delimit the adopted terminology or to present an explicit definition of what multiculturalism concept was applied.

This review also aimed to get to know the state of the art in creativity and multiculturalism research in terms of publication number, origin and design. The figures demonstrated an increasing tendency to publish articles in the area, especially involving adult participants. In addition, the continuity of the research objectives over the study period was perceived. Seventy-five percent of the studies that intended to evidence the relation between multiculturalism and creativity, bilingualism, and other psychological variables had been published until 2012. On the other hand, the more recent studies aimed to deepen the understanding of the relation between the concepts. Eighty percent of the articles in which mechanisms and conditions are underlying creative development in multicultural individuals have been published as from 2012 .

Overall, however, the number of articles identified was relatively low, considering the importance of the theme. The national borders are more fluid, with increasing movements of people among the countries (United Nations, 2015). Research information is essential for support policies and initiatives (Flick, 2009), which can contribute to the inclusion and adaptation of multicultural people, favoring creativity ( $\mathrm{Li}$ et al., 2015). The researchers' interest in these 
themes in regions with greater migration flows is noteworthy.

According to the Global Migration Report (United Nations, 2015), about two thirds of all migrants in the world live in Europe (76 million) or in Asia (75 million). Besides receiving many migrants, the continents held the largest number of people who abandoned their origins to live in other countries. In 2015, Asia and Europe represented, respectively, the origin of $43 \%$ and $25 \%$ of all emigrants in the world (United Nations, 2015). This could explain the number of articles identified in this review originating in the Asian $(n=21)$ and European continents $(n=14)$.

In a comparison among countries, the United States was the country that most published on multiculturalism and creativity $(n=10)$. It is not surprising that North Americans take particular interest in subjects linked to cultural blending. The USA, considered to be the land of opportunities, is still the most coveted destination in the world. The country by far receives the largest number of international migrants in the world. In 2015 , the USA received almost four times more immigrants than the second on the list, Germany (United Nations, 2015).

When compared to other countries, Brazil currently is not considered a strong attraction hub of immigration (Paiva \& Leite, 2014). Perhaps that is why no publication has been identified in the country that was aimed at investigating creativity and multiculturalism. According to Paiva and Leite, however, in recent years, the predominant South-North movement of people has weakened, and countries like Brazil are emerging as a receiver hub for foreigners. Factors like economic growth, the country's inclusion in international organizations, the social bonds with other countries and the Brazilian public policies influence the interest in Brazil as a destination for people from other countries. Especially for refugees, the country's attractions have truly captured.

According to the report of the National Refugee Committee (2016), in the past five years, the number of refugee claims increased by $2,868 \%$ in Brazil. At the end of 2015 , more than 25 thousand refugee claims were awaiting a response, mostly of Haitian origins. Therefore, reflections are due about the cultural exchange expectations in upcoming years and about the importance of studying the creative development of people who will experience an acculturation process in Brazil.

By the way, the refugee crisis has been experienced around the world. According to the annual report of the United Nations High Commissioner for Refugees (2015), the annual record in the number of refugees was broken in 2014, as a consequence of territorial, political and religious conflicts, having reached about 60 million people. In recent years, the number of refugees around the world reached the highest level since the Second World War.

This situation represents a source of concern for governments and populations. As these foreigners are integrated in the receiving communities, creative solutions can turn problems into comparative advantages. According to Alencar and Fleith (2009), creativity is an element of survival and progress. In that sense, studying creativity, as a fruit of refugees' multicultural experience can be relevant. Despite the significant increase in the number of refugees and the critical conditions experienced, none of the 30 articles identified in this study investigated the creativity related to multiculturalism deriving from the movement of refugees. Therefore, that is one of the possible promising niches for future research.

In the articles analyzed from the perspective of the research sample, adult participants, students and professionals were predominant. That can be related to the fact that $72 \%$ of the international migrants is between 20 and 64 years of age and only $15 \%$ is younger than 20 years (United Nations, 2015). That figure should not be considered in isolation. In its report, the United Nations Organization highlights that, although most migrants are in the working-age range, many migrant children are born in host countries and are not considered in this rate. These children are part of multicultural families, which is the case of the $44^{\text {th }}$ president of the United States for example, Barack Obama, who is son to a Kenyan father and North American 
mother. Despite being a North American citizen, he has certainly experienced multiculturalism. Greater attention to the group of first or secondgeneration young migrants is due in research in this area.

\section{Final Considerations}

In view of the results found, it can be concluded that, in general, creativity and multiculturalism are interconnected phenomena. That is a theme of interest to researchers in different countries around the world, especially in regions with greater migration flows. In Brazil, no publications have been identified. There are perspectives that, in the coming years, this theme will gain representativeness for the country, arousing the researchers' interest.

In view of the state of the art between 2010 and 2015, the study of creativity should be broadened, focusing on multicultural children and adolescents. The school, being the environment where this audience interacts, can also be investigated from the development perspective of creative potential. Besides young people, refugees, a group that has grown in function of conflicts around the world, has been a neglected audience in research and can be a relevant research niche. In addition, the use of the term multiculturalism can be investigated, considering more specific terminologies of each approach or specifically delimiting the definition of the concept. As a study limitation, the restriction to journal publications is appointed, as Master's theses and Doctoral dissertations were omitted.

\section{References}

Alencar, E. M. L. S., \& Fleith, D. S. (2009). Criatividade: Múltiplas perspectivas [Creativity: Multiple perspectives]. Brasília, DF: Editora da Universidade de Brasília.

Amabile, T. M. (1996). Creativity in context. Update to the social psychology of creativity. Boulder, CO: Westview Press.

American Psychological Association. (2010). Publication manual od the American Psychological Association. Washington, DC: Author.
Aronowitz, M. (1984). The social and emotional adjustment of immigrant children. International Migration Review, 26, 89-110.

Benet-Martínez, V., Leu, J., Lee, F., \& Morris, M. W. (2002). Negotiating biculturalism: Cultural frame switching in biculturals with oppositional versus compatible cultural identities. Journal of Cross-Cultural Psychology, 33(5), 492-516. doi: 10.1177/0022022102033005005

Benet-Martínez, V., \& Haritatos, J. (2005). Bicultural identity integration (BII): Components and psychosocial antecedents. Journal of Personality, 73(4), 1015-1050. doi: 10.1111/j.14676494.2005.00337.x

Berry, J. W. (1990). Psychology of acculturation. In J. Berman (Ed.), Nebraska symposium on motivation: Cross-cultural perspectives. Current theory and research in motivation (pp. 201-234). Lincoln, NE: University of Nebraska Press.

Berry, J. W., Kim, U., \& Boski, P. (1987). Psychological acculturation of immigrants. In Y. K. Young \& W. B. Gudykunst (Eds.), Cross-cultural adaptation: Current theory and research (pp. 312326). Newbury Park, CA: Sage.

Berry, J. W., Kim, U., Minde, T., \& Mok, D. (1987). Comparative studies of acculturative stress. International Migration Review, 21(3), 491-511. doi: $10.2307 / 2546607$

Berry, J. W., \& Sam, D. L. (1997). Acculturation and adaptation. In J. W. Berry, M. H. Segall, \& C. Kagicibaci (Eds.), Handbook of cross-cultural psychology: Vol. 31. Social behaviour and application (pp. 291-326). Boston, MA: Allyn \& Bacon.

Betz, E. (2014). Polynesian youth hip hop: Intersubjectivity and Australia's multicultural audience. Ethnomusicology Forum, 23(2), 247-265. doi: http://dx.doi.org/10.1080/17411912.2014.9266 30

Breakwell, G. M. (1995). Research: Theory and methods. In G. M. Breakwell, S. Hammond \& C. Fife-Schow (Eds.), Research methods in psycho$\operatorname{logy}$ (pp. 5-15). London: Sage.

Chang, J. H., Hsu, C. C., Shih, N. H., \& Chen, H. C. (2014). Multicultural families and creative children. Journal of Cross-Cultural Psychology, 45(8), 1288-1296. doi: $10.1177 / 0022022114537556$

Chang, J. H., Su, J. C., \& Chen, H. C. (2015). Cul- 
tural distance between parents' and children's creativity. Cultural Diversity and Ethnic Minority Psychology, 21(3), 477-485. doi: 10.1037/ a0037539

Chao, M. M., Kung, F. Y. H., \& Yao, D. J. (2015). Understanding the divergent effects of multicultural exposure. International Journal of Intercultural Relations, 47(2), 78-88. doi: 10.1016/j. ijintrel.2015.03.032

Cheng, C. Y., \& Leung, A. K. (2012). Revisiting the multicultural experience-creativity link: The effects of perceived cultural distance and comparison mind-set. Social Psychological \& Personality Science, 4(4), 475-482. doi: $10.1177 / 1948550612462413$

Cheng, C.-Y., Leung, A. K.-Y., \& Wu, T.-Y. (2011). Going beyond the multicultural experiencecreativity link: The mediating role of emotions. Journal of Social Issues, 67(4), 806-824. doi: 10.1111/j.1540-4560.2011.01729.x

Cheng, C.-Y., Sanchez-Burks, J., \& Lee, F. (2008). Connecting the dots within: Creative performance and identity integration. Psychological Science, 19(1), 1177-1183. doi: 10.1111/j.14679280.2008.02220.x.

Cho, J., \& Morris, M. W. (2015). Cultural study and problem-solving gains: Effects of study abroad, openness, and choice. Journal of Organizational Behavior, 36(7), 944-966. doi: 10.1002/job.2028

Chua, R. Y. J., Morris, M. W., \& Mor, S. (2012). Collaborating across cultures: Cultural metacognition and affect-based trust in creative collaboration. Organizational Behavior and Human Decision Processes, 118(2), 116-131. doi: http:// dx.doi.org/10.1016/j.obhdp.2012.03.009

Crisp, R. J., \& Turner, R. N. (2011). Cognitive adaptation to the experience of social and cultural diversity. Psychological Bulletin, 137(2), 242 266. doi: $10.1037 / \mathrm{a} 0021840$

Crotty, S. K., \& Brett, J. M. (2012). Fusing creativity: Cultural metacognition and teamwork in multicultural teams. Negotiation and Conflict Management Research, 5(2), 210-234. doi: 10.1111/j.1750-4716.2012.00097.x

Estatuto da Criança e do Adolescente [Child and Adolescent Statute]. (1990). Brasília, DF: Presidência da República.

Fee, A., \& Gray, S. J. (2012). The expatriate-creativity hypothesis: A longitudinal field test. Human Relations, 65(12), 1515-1538. doi: $10.1177 / 0018726712454900$
Fleith, D. S., \& Costa, A. L., Jr. (2005). Métodos de pesquisa em psicologia do desenvolvimento: $\mathrm{O}$ que é relevante considerar. In M. A. Dessen \& A. L. Costa Junior (Eds.), A ciência do desenvolvimento humano: Tendências atuais e perspectivas futuras [Human developmental science: Present trends and future perspectives] (pp. 37-49). Porto Alegre, RS: Artmed.

Flick, U. (2009). Introdução à pesquisa qualitativa [Introduction to the qualitative research] $\left(3^{\text {rd }}\right.$ ed.). São Paulo, SP: Artmed.

Friedman, R., \& Liu, W. (2009). Biculturalism in management: Leveraging the benefits of intrapersonal diversity. In R. S. Wyer, C.-Y. Chiu, \& Y.-Y. Hong (Eds.), Understanding culture: Theory, research, and application (pp. 343-360). New York: Psychology Press.

Guilford, J. P. (1950). Creativity. American Psychologist, 5(9), 444-454. doi: 10.1037/h0063487

Guilford, J. P. (1959). Traits of creativity. In H. H. Anderson (Ed.), Creativity and its cultivation (pp. 142-161). New York: Harper.

Guilford, J. P. (1967). The nature of human intelligence. New York: McGraw-Hill.

Goclowska, M. A., \& Crisp, R. J. (2014). How dual-identity processes foster creativity. Review of General Psychology, 18(3), 216-236. doi: 10.1037/gpr0000008

Goff, K., \& Torrance, E. P. (2002). Abbreviated Torrance Test for Adults. Bensenville, IL: Scholastic Testing Service.

Inglis, C. (1996). Multiculturalism: New policy responses to diversity. Paris: United Nations Educational, Scientific and Cultural Organization.

Kharkhurin, A. V. (2010). Sociocultural differences in the relationship between bilingualism and creative potential. Journal of CrossCultural Psychology, 41(5), 776-783. doi: $10.1177 / 0022022110361777$

Klimczuk, A. (2014). Barriers to the development of creative industries in culturally diverse region. Coactivity: Philosophy, Communication, 22(2), 145-152. doi: 10.3846/cpc.2014.13

Krug, M. (2013). International creation examining cross-cultural influences in Ernest Hemingways for whom the bell tolls. Interdisciplinary Literary Studies, 15(2), 261-288.

Kuo, B. C. H. (2014). Coping, acculturation, and psychological adaptation among migrants: A theoretical and empirical review and syn- 
thesis of the literature. Health Psychology and Behavioral Medicine, 2, 16-33. doi: 10.1080/21642850.2013.843459

Lee, H., \& Kim, K. H. (2011). Can speaking more languages enhance your creativity? Relationship between bilingualism and creative potential among Korean American students with multicultural link. Personality and Individual Differences, 50(8), 1186-1190. doi: 10.1016/j. paid.2011.01.039

Leung, A. K.-Y., \& Chiu, C.-Y. (2010). Multicultural experience, idea receptiveness, and creativity. Journal of Cross-Cultural Psychology, 41(5), 723-741. doi: 10.1177/0022022110361707

Leung, K., \& Wang, J. (2015). Social processes and team creativity in multicultural teams: A sociotechnical framework. Journal of Organizational Behavior, 36(7), 1008-1025. doi: 10.1002/ job. 2021

Li, C.-R., Lin, C.-J., Tien, Y.-H., \& Chen, C.-M. (2015). A multilevel model of team cultural diversity and creativity: The role of climate for inclusion. The Journal of Creative Behavior, 1-22. doi: 10.1002/jocb.93

Maddux, W. W., Adam, H., \& Galinsky, A. D. (2010). When in Rome . . Learn why the Romans do what they do: How multicultural learning experiences facilitate creativity. Personality and Social Psychology Bulletin, 36(6), 731-741. doi: 10.1177/0146167210367786

Malzberg, B., \& Lee, E. (1956). Immigration and mental disease. New York: Social Science Research Council.

Mendonça, P. V. C. F., \& Fleith, D. S. (2005). Relação entre criatividade, inteligência e autoconceito em alunos monolingues e bilíngües [Relationship between creativity, intelligence and self-concept in monolingual and bilingual students]. Psicologia Escolar e Educacional, 9(1), 59-70.

Mok, A., \& Morris, M. W. (2012). Managing two cultural identities: The malleability of bicultural identity integration as a function of induced global or local processing. Personality and Social Psychology Bulletin, 38(2), 233-246. doi: $10.1177 / 0146167211426438$

Mok, A., Morris, M. W., Benet-Martínez, V., \& Karaki Tapoglu-Aygun, Z. (2007). Embracing American culture: Structures of social identity and social networks among first-generation bi- culturals. Journal of Cross-Cultural Psychology, 38(5), 629-635.

Moro, M. R. (2014). Risk and creativity in adolescence within a multicultural society. Interazioni, 1, 21-31.

Nakano, T. C. (2005). Pesquisa em criatividade: Análise da produção científica do banco de teses da Capes (1996-2001). In G. P. Witter (Ed.), Metaciência e psicologia [Meta-science and psychology] (pp .35-48). Campinas, SP: Alínea.

Nakano, T. C., \& Wechsler, S. M. (2007). Criatividade: Características da produção científica brasileira [Creativity: Characteristics of the Brazilian scientific production]. Avaliação Psicológica, 6(2), 261-270.

National Refugee Committee. (2016). Sistema de Refúgio Brasileiro: Desafios e perspectivas [Brazilian refuge system: Challenges and perspectives]. Brasília, DF: Ministério da Justiça. Retrieved from http://www.acnur.org/fileadmin/scripts/ doc.php?file=fileadmin/Documentos/portugues/ Estatisticas/Sistema_de_Refugio_brasileiro_-Refugio_em_numeros_-_05_05_2016

Nouri, R., Erez, M., Rockstuhl, T., Ang, S., LeshemCalif, L., \& Rafaeli, A. (2013). Taking the bite out of culture: The impact of task structure and task type on overcoming impediments to crosscultural team performance. Journal of Organizational Behavior, 34(6), 739-763. doi: 10.1002/ job. 1871

Paiva, A. L. B., \& Leite, A. P. M. R. (2014). Da emigração à imigração? Por uma análise do perfil migratório brasileiro nos últimos anos [From emmigration to immigration? For an analysis of the Brazilian migratory profile in the last years]. Ars Histórica, 7, 1- 20.

Paletz, S. B. F., Miron-Spektor E., \& Lin, C. (2014). A cultural lens on interpersonal conflict and creativity in multicultural environments. Psychology of Aesthetics, Creativity, and the Arts, 8(2), 237-252. doi: 10.1037/a0035927

Rudmin, F. W. (2009). Catalogue of acculturation constructs: Descriptions of 126 taxonomies, 1918-2003. Online Readings in Psychology and Culture, 8(1). doi: 10.9707/ 2307-0919.1074

Saad, C. S., Damian, R. I., Benet-Martínez, V., Moons, W. G., \& Robins, R. W. (2012). Multiculturalism and creativity: Effects of cultural context, bicultural identity, and ideational fluency. Social 
Psychological and Personality Science, 4(3), 369-375. doi: 10.1177/1948550612456560

Sam, D. L., \& Berry, J. W. (2010). Acculturation: When individuals and groups of different cultural backgrounds meet. Perspectives on Psychological Science, 5, 472-481. doi: $10.1177 / 1745691610373075$

Stahl, G. K., Makela, K., Zander, L., \& Maznevski, M. L. (2010). A look at the bright side of multicultural team diversity. Scandinavian Journal of Management, 26(4), 439-447. doi: 10.1016/j. scaman.2010.09.009

Storme, M., Lubart, T., Myszkowski, N., Cheung, P. C., Tonge, T., \& Lau, S. (2015). A cross-cultural study of task specificity in creativity. The Journal of Creative Behavior, 1-15. doi: 10.1002/ jocb. 123

Tadmor, C. T., Galinsky, A. D., \& Maddux, W. W. (2012). Getting the most out of living abroad: Biculturalism and integrative complexity as key drivers of creative and professional success. Journal of Personality and Social Psychology, 103(3), 520-542. doi: 10.1037/a0029360

Tadmor, C. T., Hong, Y.-Y., Chao, M. M., Wiruchnipawan, F., \& Wang, W. (2012). Multicultural experiences reduce intergroup bias through epistemic unfreezing. Journal of Personality and Social Psychology, 103(5), 750-772. doi: 10.1037/a0029719

Tadmor, C. T., Satterstrom, P., Jang, S., \& Polzer, J. T. (2012). Beyond individual creativity: The superadditive benefits of multicultural experience for collective creativity in culturally diverse teams. Journal of Cross-Cultural Psychology, 43(3), 384-392.

Torrance, E. P. (1998). The Torrance tests of creative thinking norm-technical manual figural (streamlined) forms $A \& B$. Bensenville, IL: Scholastic Testing Service.

United Nations. (2015). International Migration Report 2015: Highlights. New York: Author.

United Nations High Commissioner for Refugees. (2015). UNHCR Global trends 2014: Force displacement in 2014. Genebra: Author.
Viki, G. T., \& Williams, M. L. J. (2014). The role of identity integration in enhancing creativity among mixed-race individuals. The Journal of Creative Behavior, 48(3), 198-208. doi: $10.1002 /$ jocb. 48

Wechsler, S. M., \& Nakano, T. C. (2003). Produção brasileira em criatividade: $\mathrm{O}$ estado da arte [Brazilian production in creativity: The state of the art]. Escritos sobre Educação, 2(2), 43-50.

Witter, G. P. (1999). Metaciência e leitura. In G. P. Witter (Ed.), Leitura: Textos e pesquisas [Reading: Texts and researches] (pp. 13-22). Campinas, SP: Alínea.

Yoon, E., Chang, C. T., Kim, S., Clawson, A., Cleary, S. E., Hansen, M., ... Gomes, A. (2012). A metaanalysis of acculturation/enculturation and mental health. Journal of Counseling Psychology, 60, 1-16. doi: 10.1037/a0030652

Zanella, A. V., \& Titon, A. P. (2005). Análise da produção científica sobre criatividade em programas brasileiros de pós-graduação em psicologia [Scientific production analysis about creativity in Brazilian psychology graduate programs]. Psicologia em Estudo, 10(2), 305-316. doi: 10.1590/S1413-73722005000200018

Zhan, S., Bendapudi, N., \& Hong, Y-Y. (2015). Re-examining diversity as a double-edged sword for innovation process. Journal of Organizational Behavior, 36(7), 1026-1049. doi: 10.1002/ job.2027

Zimmer, M. C., \& Alves, U. K. (2014). O impacto do bi/multilinguismo sobre o potencial criativo em sala de aula: Uma abordagem via teoria dos sistemas dinâmicos. Educação e Contemporaneidade, 23(41), 77-89.

(cc) BY 1 (C) The Author(s), 2018. Open Access. This article is distributed under the terms of the Creative Commons Attribution 4.0 International License (http://creativecommons.org/licenses/by/4.0/), which permits unrestricted use, distribution, and reproduction in any medium, provided you give appropriate credit to the original author(s) and the source, provide a link to the Creative Commons license, and indicate if changes were made. 